\title{
DETERMINAN PROFITABILITAS: KAJIAN PENGELOLAAN FAKTOR INTERNAL DAN EKSTERNAL PERUSAHAAN TEKSTIL DAN PRODUK TEKSTIL (TPT) YANG TERDAFTAR DI BURSA EFEK INDONESIA
}

\author{
Nugraheni Siwi \\ Fakultas Ekonomi dan Bisnis Universitas Pembangunan Nasional Veteran Jakarta \\ Email: siwinugraheni.1983@yahoo.com
}

KETERANGAN ARTIKEL

Riwayat Artikel

Diterima: 1 Mei 2019

Direvisi : 1 Juni 2019

Disetujui: 31 Juni 2019

Klasifikasi JEL

M41 dan M49

Keywords: ROA, current ratio, and interest rates

Kata kunci: ROA, current ratio, dan tingkat suku bunga

\section{Abstract}

The aim of this study is to examine the effect of internal and external factors on companies profitability and products of textile indutries listed on Indonesian Exchanges (IDX). This study show that partially, current ratio and interest rates have significant effect on ROA. Simultanously, internal and external factors have significant effect on ROA. Manajerial implication of this study is companies should apply liquidity risk mgt such as, mitigation on liquidity crisis, liquidity risk bearing, and looking for another funding resources to decrease interest rate expenses.

\begin{abstract}
Abstrak
Tujuan dari penelitian ini adalah untuk mengetahui pengaruh faktor internal dan eksternal terhadap profitabilitas (Return on Assets) perusahaan tekstil dan produk tekstil yang go public di Bursa Efek Indonesia dengan menggunakan sampel laporan keuangan perusahaan TPT tahun 2015-2017. Hasil penelitian menunjukkan secara parsial variabel internal yang berpengaruh signifikan adalah variabel likuiditas (current ratio) dan faktor eksternal yang berpengaruh signifikan adalah tingkat suku bunga. Secara simultan, faktor internal dan faktor eksternal secara serempak berpengaruh signifikan terhadap profitabilitas perusahaan TPT. Implikasi manajerial berdasarkan penelitian ini adalah perusahaan TPT perlu menerapkan manajemen risiko likuiditas seperti mitigasi krisis likuiditas dan liquidity risk bearing analysis serta mencari alternatif pembiayaan selain utang bank untuk menekan beban bunga
\end{abstract}

\section{PENDAHULUAN}

Industri tekstil dan produk tekstil (TPT) merupakan salah satu industri yang penting di Indonesia. Hal tersebut disebabkan industri TPT merupakan industri padat karya yang menyerap banyak tenaga kerja dan berorientasi ekspor sehingga mempunyai potensi untuk dikembangkan sebagai salah satu penyokong perekonomian nasional (Kemenperin, 2018).

Meskipun memiliki peran strategis dalam perekonomian nasional, industri ini mengalami fluktuasi sepanjang tahun 20052018. Data ekspor produk TPT tahun 2005- 
Nugraheni Siwi: Determinan Profitabilitas ...

2018 terus mengalami penurunan (Kemenperin, 2018). Padahal pada tahun 2009 industri TPT berkontribusi 2,1\% terhadap PDB tahun 2009 (BPS, 2010). Posisi Indonesia sebagai pengekspor TPT pada tahun 2010 ada di peringkat 8 namun saat ini turun di posisi 10 (Investor Daiy, 2018). Peran industri TPT sebagai industri padat karya pun mulai menurun. Pada tahun 2012, jumlah tenaga kerja yang diserap industri TPT sebanyak 482.349 tenaga kerja, sedangkan pada 2013 makin menurun menjadi 427.083 atau turun 11,46\% (BPS, 2013). Data tersebut menunjukkan adanya PHK yang cukup besar di industri TPT.

Kondisi makro sebagai faktor eksternal dapat mempengaruhi kinerja perusahaan TPT. Banyak peneliti percaya bahwa beberapa variabel ekonomi seperti suku bunga tinggi, laju inflasi tinggi menyebabkan perusahaan mengalami kesulitan keuangan yang dapat menurunkan kinerja keuangan. Kebijakan pemerintah dalam menetapkan tarif dasar listrik bagi industri juga dianggap mempengaruhi profitabilitas perusahaan karena berkaitan dengan besarnya biaya produksi perusahaan.

Upaya yang harus dilakukan perusahaan tekstil untuk meningkatkan profitabilitas dari faktor internal adalah meningkatkan produksi, mengurangi biaya dan pengeluaran operasional, mengurangi tenaga kerja, mengurangi pinjaman, dan biaya bunga (Virambai, 2010). Diharapkan dengan adanya pengelolaan dari segi produksi dan pengendalian biaya akan dapat berdampak terhadap peningkatan profitabilitas.

Hermawan (2011) dalam penelitiannya terhadap perkembangan produksi TPT Indonesia tahun 2011 menyatakan adanya pengaruh faktor makroekonomi yang signifikan berupa suku bunga dan penyesuaian nilai tukar rupiah oleh otoritas moneter. Hal ini menunjukkan adanya hubungan antara pengaruh faktor eksternal terhadap kinerja perusahaan TPT.
Faktor internal berupa likuiditas, total aset turnover, dan debt ratio serta pengaruh faktor eksternal berupa suku bunga dan inflasi memberikan pengaruh signifikan terhadap profitabilitas perusahaan TPT (Purwadi, 2013). Berdasarkan pertimbangan tersebut maka penelitian ini bermaksud untuk melihat pengaruh faktor-faktor internal melalui pengelolaan likuiditas, pengelolan utang, dan jumlah karyawan, serta pengaruh faktor-faktor eksternal berupa suku bunga, inflasi dan kebijakan tarif dasar listrik terhadap profitabilitas perusahaan TPT go-public di Bursa Efek Indonesia selama periode tahun 2015-2017.

Ada pun peneliti ini bertujuan untuk mengetahui apakah ada pengaruh parsial dan simultan dari faktor-faktor internal seperti current ratio, debt to total asset, dan jumlah karyawan serta faktor-faktor eksternal seperti suku bunga, inflasi, dan kebijakan tarif dasar listrik terhadap profitabilitas perusahaan tekstil dan produk tekstil dalam hal ini Return on Assets (ROA).

\section{KAJIAN LITERATUR DAN PENGEMBANGAN HIPOTESIS \\ Profitabilitas \\ Profitabilitas mengindikasikan seberapa} efektif manajemen memperoleh laba dan penjualan. Profitabilitas memiliki 2 konsep, yaitu:

1. Profitablitas dalam kaitannya dengan penjualan menggunakan ukuran laba kotor dan laba bersih. Profitabilitas dalam konsep ini menggunakan ukuran net profit margin (NPM).

2. Profitabilitas dalam kaitannya dengan investasi menggunakan ukuran ROI (Return on Investment) atau ROA (Return on Asset).

Profitability ratio menunjukkan pengaruh gabungan dari likuiditas, pengelolaan aktiva, dan pengelolaan utang terhadap hasil operasi (Margaretha, 2014) Hal tersebut menunjukkan bahwa profitabilitas yang diperoleh perusahaan berkaitan dengan faktor internal perusahaan yang berkaitan dengan kemampuan perusahaan mengelola 
likuiditas, aset perusahan atau aktiva dan manajemen utang.

ROA menunjukkan kemampuan perusahaan dalam menghasilkan laba atas setiap aktiva yang digunakan. Saputro (2019) menyatakan bahwa profitabilitas dipengaruhi faktor internal dan eksternal. Faktor internal meliputi pengelolaan aset, pengelolaan likuiditas, dan pengelolaan utang yang digunakan untuk membiayai aktiva.

\section{Likuiditas}

Pengelolaan likuiditas sangat penting untuk dilakukan karena berpengaruh terhadap profitabilitas perusahaan. Manajer keuangan selalu dihadapkan pada persoalan likuiditas (Ejelly,2004). Kelebihan likuiditas menunjukkan bahwa perusahaan memiliki dana berlebih yang bisa menurunkan produktivitas, di sisi lain perusahaan juga harus memiliki sejumlah kas yang cukup untuk menghadapi situasi yang mungkin tidak diharapkan sebelumnya. Perusahaan yang memiliki profitabilitas tinggi menunjukkan kemampuannya untuk menambah aset yang dapat digunakan untuk mengembangkan usahanya, sedangkan perusahaan dengan profitabilitas rendah akan sulit bersaing dan bertahan (Bekeris, 2012).

\section{Debt to Total Assets}

Faktor internal lain yang berkaitan dengan profitabilitas adalah rasio utang. Rasio utang mengungkapkan sejauh mana perusahaan dibiayai utang dan kemampuan perusahan untuk melunasi utang (Margaretha, 2014).

Waqas dan Rahman (2014) dalam penelitiannya menemukan adanya pengaruh negatif dan signifikan antara debt to total asset ratio terhadap profitabilitas. Cekrezi (2015) juga menyatakan tingkat debt ratio yang tinggi akan berdampak negatif terhadap profitabilitas. Purwadi (2013) juga mendapatkan adanya pengaruh negatif debt to total asset ratio terhadap profitabilitas perusahaan tekstil. Pada dasarnya investor tak menyukai perusahaan dengan debt ratio yang tinggi karena semakin tinggi debt to total asset ratio maka makin besar pula risiko yang ditanggung perusahaan.

\section{Inflasi}

Salvatore dan Diulio (2003) menyatakan bahwa inflasi adalah kenaikan tingkat harga secara umum, bukan hanya barang dan jasa tertentu saja. Para ekonom mengidentifikasikan penyebab inflasi menjadi dua. Pertama, inflasi tarikan permintaan (demand pull inflation) yaitu inflasi yang terjadi ketika pengeluaran agregat melampaui tingkat output kesempatan kerja penuh (full employment). Inflasi ini ditandai naiknya harga dan naiknya tingkat output. Penyebab kedua dalah inflasi dorongan biaya (cost push inflation), dimana inflasi berasal dari kenaikan biaya produksi barang dan jasa seperti upah dan harga bahan baku.

Saputro (2019) menemukan adanya pengaruh negatif inflasi namun tak signifikan antara inflasi dan ROA terhadap profitabilitas perusahaan pertambangan di Indonesia, sedangkan Purwadi (2013) menyatakan adanya hubungan negatif dan signifikan antara inflasi dengan profitabilitas perusahaan tekstil di Indonesia.

\section{Suku Bunga}

Suku bunga adalah harga yang harus dibayar atas modal pinjaman serta keuntungan modal yang merupakan hasil dari modal ekuitas (Brigham, 2001). Kenaikan suku bunga akan menyebabkan utang perusahaan pada pihak ketiga berupa beban bunga akan meningkat (Purwadi, 2013). Hermawan (2011) dalam penelitiannya terhadap perkembangan produksi TPT Indonesia tahun 2011 menyatakan adanya pengaruh faktor makroekonomi yang signifikan berupa suku bunga dan penyesuaian nilai tukar rupiah oleh otoritas moneter. 
Nugraheni Siwi: Determinan Profitabilitas ...

\section{Kebijakan Tarif Dasar Listrik}

Listrik merupakan komponen penting kegiatan industri. Setiap tahun pemerintah menetapkan kebijakan tarif dasar listrik (TDL) yang bisa berbeda ataupun sama dengan tahun sebelumnya. Besar kecilnya tarif dasar listrik akan berpengaruh terhadap biaya produksi perusahaan dan pada akhirnya akan berimbas pada laba yang akan diperoleh perusahaan. Kenaikan tarif dasar listrik menyebabkan industri rumah tangga di Indonesia harus menaikkan harga jual produknya untuk menutupi biaya produksi (Wiharja dan Natalia, 2013)

Kenaikan tarif dasar listrik berimbas pada berkurangnya konsumsi listrik oleh perusahaan TPT di Jawa Barat dan beralih pada sumber energi alternatif untuk menekan biaya produksi (Ermawati, 2014). Hal ini menunjukkan adanya perusahaan TPT yang merasakan peningkatan beban operasional akibat kenaikan TDL yang akan berpengaruh terhadap profitabilitas perusahaan.

\section{Hipotesis Penelitian}

Berdasarkan serangkaian kajian dan penelitian terdahulu yang dilakukan maka hipotesis dalam penelitian ini dapat dirumuskan sebagai berikut:

$\mathrm{H}_{1}=$ Terdapat pengaruh signifikan likuiditas terhadap profitabilitas perusahaan TPT

$\mathrm{H}_{2}=$ Terdapat pengaruh signifikan debt to total assets terhadap profitabilitas perusahaan TPT

$\mathrm{H}_{3}=$ Terdapat pengaruh signifikan jumlah karyawan terhadap profitabilitas perusahaan TPT

$\mathrm{H}_{4}=$ Terdapat pengaruh signifikan inflasi terhadap profitabilitas perusahan TPT

$\mathrm{H}_{5}=$ Terdapat pengaruh signifikan suku bunga terhadap profitabilitas perusahaan TPT

$\mathrm{H}_{6}=$ Terdapat pengaruh signifikan tarif dasar listrik terhadap profitabilitas perusahaan TPT

\section{PERUMUSAN MODEL PENELITIAN}

Model dalam penelitian ini adalah serbagai berikut:

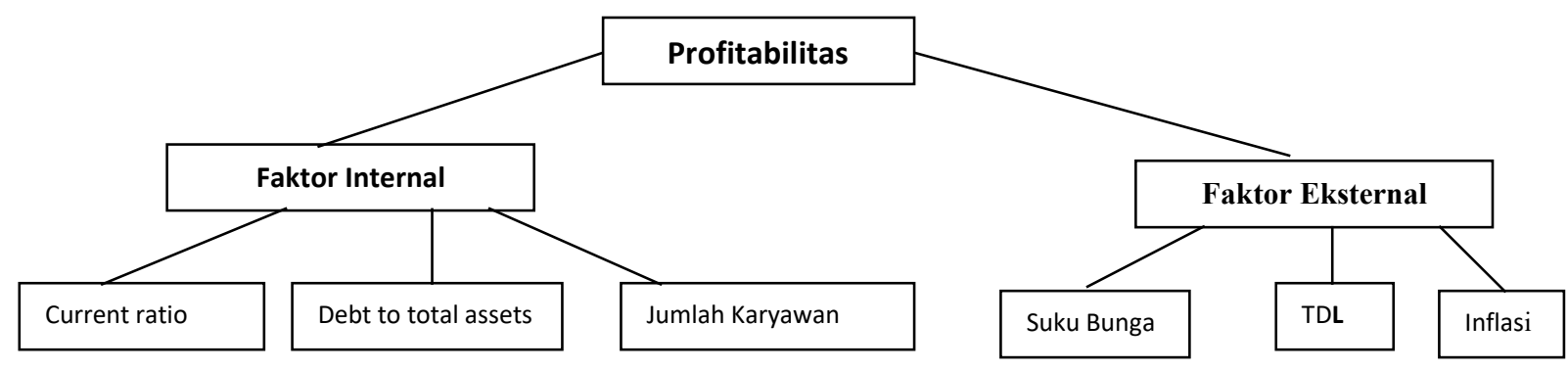

Gambar 1. Model penelitian

\section{METODOLOGI PENELITIAN}

Metode penarikan sampel pada penelitian ini menggunakan metode purposive sampling dimana sampel diambil berdasarkan kriteria tertentu. Sampel penelitian ini adalah perusahaan-perusahaan produsen tekstil dan produk tekstil (TPT). Jumlah populasi yaitu perusahaan tekstil yang terdaftar di BEI sebanyak 18 perusahaan. Jumlah sampel yang diambil sebanyak 9 perusahaan TPT yang terdaftar di Bursa Efek Indonesia. Sampel perusahaan diambil berdasarkan kriteria berikut:

1. Perusahaan TPT yang sudah berdiri sejak sebelum 2015. Perusahaan tersebut sudah go public di Bursa Efek Indonesia (BEI) sampai sekarang. 
2. Perusahaan tersebut menyampaikan laporan keuangannya secara rutin sejak tahun 2015- 2017.

Data pada penelitian ini berupa annual report perusahaan TPT yang memuat rasio keuangan dan data jumlah karyawan setiap tahun. Data yang berhubungan dengan variabel makroekonomi berasal dari laporan tahunan BPS (Biro Pusat Statistik) dan Bank Indonesia.

\section{Definisi Variabel Operasional Variabel Dependen/Variabel Terikat}

Variabel dependen atau variable terikat dalam penelitian ini adalah profitabilitas dalam hal ini Return on Assets (ROA), yaitu perbandingan antar Earning After Taxes (EAT) dengan Total Aset.

\section{Variabel Independen/ Variabel Bebas}

Variabel independen dalam penelitian ini adalah:

Variabel Likuiditas $\left(\mathrm{X}_{1}\right)$

Likuiditas dalam penelitian ini menggunakan current ratio yang dirumuskan sebagai berikut:

$$
\text { Current ratio }=\frac{\text { Jumlah aset lancar }}{\text { Liabilitas lancar }}
$$

Variabel Debt to Total Assets $\left(\mathrm{X}_{2}\right)$

Debt to total assets menggambarkan seberapa besar aset perusahaan yang dibiayai dari utang. Debt to Total Assets dirumuskan sebagai berikut:

$$
\text { Debt to Total Assets }=\frac{\text { Total liabilitas }}{\text { Total Assets }}
$$

Variabel Jumlah Karyawan $\left(\mathrm{X}_{3}\right)$

Jumlah karyawan merupakan bagian dari komponen biaya produksi. Variabel jumlah karyawan berasal dari jumlah total karyawan perusahaan tekstil dan produk tekstil di bagian produksi dan manajemen.
Variabel Inflasi $\left(\mathrm{X}_{4}\right)$

Inflasi adalah tingkat kenaikan harga secara umum. Variabel inflasi berasal dari data inflasi tahunan yang dikeluarkan oleh Bank Indonesia.

\section{Variabel Suku Bunga $\left(X_{5}\right)$}

Suku bunga yang ditetapkan oleh BI merupakan acuan yang digunakan dunia perbankan dan dunia usaha. Data suku bunga dalam penelitian ini berasal dari data BI Rate rata-rata dalam satu tahun yang ditetapkan oleh Bank Indonesia.

\section{Variabel Tarif Dasar Listrik (TDL) $\left(\mathrm{X}_{6}\right)$}

Salah satu kebijakan pemerintah yang mempengaruhi dunia industri adalah penetapan tarif dasar listrik. Setiap beberapa periode pemerintah menetapkan kebijakan tarif dasar listrik untuk golongan industri dan rumah tangga. Tarif dasar listrik untuk golongan industri yang digunakan dalam penelitian ini berasal dari data rata-rata tarif dasar listrik untuk industri dalam satu tahun.

\section{Teknik Analisis}

Dalam melakukan pengujian hipotesis dan analisis data, penelitian ini menggunakan program software statistik Eviews 8. Untuk mengetahui pengaruh likuiditas, debt to total asset, jumlah karyawan, inflasi, suku bunga dan tarif dasar listrik terhadap profitabilitas maka dilakukan analisis regresi data panel karena data yang digunakan adalah data time series dan cross section. Tiga model data panel yang biasa digunakan adalah Ordinary Least Square (OLS), model fixed effect, dan model random effect. Ketiga jenis model ini akan digunakan semua untuk mengeksplorasi metode atau model mana yang paling cocok dalam penelitian ini. 


\section{HASIL DAN PEMBAHASAN \\ Analisa Data \\ Statistik Deskriptif}

Sugiyono (2010) menyatakan bahwa statistik deskriptif berfungsi mendeskripsikan atau memberi gambaran terhadap objek yang diteliti melalui data sampel atau populasi sebagaimana adanya, tanpa melakukan analisis dan membuat kesimpulan yang berlaku umum dari data tersebut. Statistik deskriptif variabel penelitian dapat dilihat pada tabel 1.

Tabel 1. Statistik Deskriptif Variabel Penelitian

\begin{tabular}{lllll}
\hline Variabel & $\mathbf{N}$ & \multicolumn{2}{c}{ Nilai } & Rata-Rata \\
\cline { 3 - 4 } & & Maksimum & Minimum & \\
\hline ROA & 27 & 67.200 & -5.900 & 20.145 \\
LICR & 27 & 2.270 & 1.521 & 0.310 \\
DTAMOD2 & 27 & 0.900 & 0.400 & 0.648 \\
LIJK & 27 & 10.526 & 5.937 & 8.274 \\
LIINF & 27 & 3.39 & 1.200 & 0.973 \\
INT & 27 & 7.520 & 0.08 & 5.494 \\
TDL & 27 & 1043.000 & 965.520 & 1001.753 \\
\hline
\end{tabular}

Sumber: Data diolah, 2019

Berdasarkan tabel 1 dapat kita lihat bahwa:

1. Nilai ROA tertinggi perusahaan TPT sebesar $67.2 \%$ dan nilai ROA terendah $-5.9 \%$. Ratarata ROA perusahaan TPT $20.145 \%$

2. Nilai current ratio perusahaan TPT tertinggi sebesar $2.207 \%$ dan nilai current ratio terendah $1.521 \%$. Rata-rata current ratio perusahaan TPT $0.310 \%$

3. Nilai debt to total assets perusahaan TPT tertinggi sebesar $0.9 \%$ sedangkan nilai debt to total assets terendah perusahaan TPT $0.4 \%$. Rata-rata debt to total assets perusahaan TPT $0.648 \%$.

4. Jumlah karyawan terbesar yang dimiliki perusahaan TPT sebesar 10526, sedangkan jumlah karyawan perusahaan TPT paling sedikit sebesar 5937. Rata rata jumlah karyawan yang dimiliki perusahaan TPT sebesar 8274.

5. Tingkat inflasi tertinggi sebesar $3.39 \%$ sedangkan terendah $1.2 \%$ dengan rata-rata inflasi $0.973 \%$.

6. Tingkat suku bunga tertinggi sebesar $7.52 \%$ sedangkan terendah $0.08 \%$ dengan ratarata sebesar $5.494 \%$

7. Tarif dasar listrik tertinggi sebesar Rp. 1043 per kwh sedangkan terendah sebesar
Rp.965.520 per kwh dengan rata-rata sebesar Rp.1001.753 per kwh.

\section{Uji Asumsi Klasik \\ Uji Normalitas}

Uji normalitas dilakukan untuk melihat apakah variabel data terdistribusi dengan normal atau tidak, hasil pengujian normalitas dapat dilihat pada tabel 2 .

Tabel 2. Hasil Uji Normalitas 1

\begin{tabular}{lc}
\hline Variabel & $\begin{array}{c}\text { Probabilitas } \\
\text { Jarque Bera }\end{array}$ \\
\hline ROA & 0.213976 \\
Current Ratio (CR) & 0.003304 \\
Debt to Total Aset (DTA) & 0.000137 \\
Jumlah Karyawan (JK) & 0.000000 \\
Inflasi (INF) & 0.000000 \\
Suku bunga (INT) & 0.006493 \\
Tarif Dasar Listrik (TDL) & 0.249799 \\
\hline
\end{tabular}

Sumber: Data diolah, 2019

Dari tabel 2 kita dapat melihat terdapat beberapa variabel yang memiliki nilai probabilitas Jarque Bera kurang dari 0.05 yang berarti data tidak terdistribusi dengan normal dan menunjukkan adanya penyebaran data dari populasi yang tidak normal. Untuk 
mengatasi distribusi data yang tidak normal maka dilakukan transformasi data. Transformasi data dapat dilakukan dengan mengolah data dalam bentuk Log, log natural, maupun bentuk kuadrat (Winarno, 2011). Pada Penelitian ini dilakukan transformasi data dalam bentuk log.

Setelah dilakukan transformasi maka hasil uji normalitas data dapat dilihat pada tabel 3.

Tabel 3. Hasil Uji Normalitas 2

\begin{tabular}{lc}
\hline Variabel & $\begin{array}{c}\text { Probabilitas } \\
\text { Jarque Bera }\end{array}$ \\
\hline ROA & 0.213976 \\
LICR & 0.604390 \\
DTAMOD2 & 0.560624 \\
LIJK & 0.763645 \\
LINF & 0.086104 \\
INT & 0.006493 \\
TDL & 0.249799 \\
\hline
\end{tabular}

Sumber: Data diolah, 2019

Dari tabel 3 kita melihat semua variabel memiliki probabilitas Jarque Berra lebih besar dari 0.05 sehingga dapat disimpulkan data terdistribusi dengan mengikuti bentuk distribusi normal.

\section{Uji Heteroskedastisitas}

Uji heteroskedastisitas dilakukan untuk menentukan apakah terdapat ketidaksamaan varian dari residual satu pengamatan ke pengamatan yang lain. Model regeresi yang baik adalah yang homoskedastis atau tidak terjadi heteroskedastisitas. Hasil pengujian heteroskedastisitas terlihat pada tabel 4 .
Tabel 4. Hasil Uji Heteroskedastisitas

\begin{tabular}{lc} 
Variabel & $\begin{array}{c}\text { Nilai Probabilitas } \\
\text { t-statistic }\end{array}$ \\
\hline ROA & 0.5434 \\
LICR & 0.4051 \\
DTAMOD2 & 0.3433 \\
LIJK & 0.1961 \\
LINF & 0.5425 \\
INT & 0.6886 \\
TDL & 0.6988 \\
\hline
\end{tabular}

Sumber: Data diolah, 2019

Dari Tabel 4 kita lihat bahwa tidak ada variabel yang mengalami masalah heteroskedastisitas karena semua memiliki nilai probabilitas $t$-statistic yang lebih besar dari 0.05 .

\section{Uji Multikolinearitas}

Uji multikolinearitas dilakukan untuk melihat ada tidaknya hubungan antar variabel bebas. Jika terjadi hubungan antar variable bebas maka variabel-variabel tidak orthogonal. Hasil uji multikolinearitas menghasilkan tidak ada multikolinearitas karena nilai korelasi antar variabel $>0.8$. Hasil pengujian multikolinearitas dapat dilihat pada tabel 5 .

Tabel 5. Hasil Uji Multikolinearitas

\begin{tabular}{llr}
\hline & Variabel & $\begin{array}{r}\text { Nilai } \\
\text { Antar Variabel }\end{array}$ \\
\hline ROA & LICR & -0.477819 \\
& DTAMOD2 & 0.109378 \\
& LIJK & 0.042440 \\
& LIINF & 0.142148 \\
& INT & -0.33862 \\
& TDL & -0.53984 \\
\hline LICR & ROA & -0.477819 \\
& DTAMOD2 & -0.044713 \\
& LIJK & 0.413222 \\
& LIINF & -0.233477 \\
& INT & -0.144034 \\
& TDL & -0.001118 \\
\hline DTAMOD2 & ROA & 0.109378 \\
& LICR & -0.044713
\end{tabular}


Nugraheni Siwi: Determinan Profitabilitas ...

\begin{tabular}{|c|c|c|}
\hline & Variabel & $\begin{array}{l}\text { Nilai Korelasi } \\
\text { Antar Variabel }\end{array}$ \\
\hline & LIJK & 0.357861 \\
\hline & LIINF & 0.301138 \\
\hline & INT & 0.294438 \\
\hline & TDL & 0.011863 \\
\hline \multirow[t]{6}{*}{ LIJK } & ROA & 0.042440 \\
\hline & LICR & 0.413222 \\
\hline & DTAMOD2 & 0.357861 \\
\hline & LIINF & 0.165575 \\
\hline & INT & 0.155878 \\
\hline & TDL & -0.39842 \\
\hline \multirow[t]{6}{*}{ LIINF } & ROA & 0.142148 \\
\hline & LICR & -0.233477 \\
\hline & DTAMOD2 & 0.301138 \\
\hline & LIJK & 0.165575 \\
\hline & INT & 0.692593 \\
\hline & TDL & -0.206165 \\
\hline \multirow[t]{6}{*}{ INT } & ROA & -0.338622 \\
\hline & LICR & -0.144034 \\
\hline & DTAMOD2 & 0.294438 \\
\hline & LIJK & 0.155878 \\
\hline & LIINF & 0.692593 \\
\hline & TDL & 0.412286 \\
\hline \multirow[t]{6}{*}{ TDL } & ROA & -0.53984 \\
\hline & LICR & -0.00118 \\
\hline & DTAMOD2 & 0.011863 \\
\hline & LIJK & -0.39842 \\
\hline & LIINF & -0.206165 \\
\hline & INT & 0.412286 \\
\hline
\end{tabular}

Sumber: Data diolah, 2019

Uji Autokorelasi

Uji autokorelasi dilakukan untuk melihat ada tidaknya residual pada satu pengamatan dengan pengamatan lain pada model regresi. Menurut Sugiyono (2010) salah satu cara untuk mengetahui ada tidaknya autokorelasi adalah dengan uji Durbin-Watson. Kriteria nilai koefisien Durbin-Watson dapat dilihat pada tabel 6 .
Tabel 6. Kriteria Nilai Durbin-Watson

Nilai Durbin- Kesimpulan

Watson

0,00-1,10 Ada autokorelasi positif

1,11-1,53 Tidak dapat diputuskan

1,54-2,46 Tidak ada autokorelasi

2,47-2,90 Tidak dapat diputuskan

2,91-4,00 Ada autokorelasi negatif Sumber: Data diolah, 2019

Berdasarkan hasil uji autokorelasi diperoleh nilai Durbin-Watson 2.270221 sehingga dapat disimpulkan tidak terjadi autokorelasi. Hasil uji Durbin Watson dapat dilihat pada tabel 7.

Tabel 7. Hasil Uji durbin Watson Weighted Test

\begin{tabular}{|c|c|c|c|}
\hline R-squared & 0.798055 & $\begin{array}{l}\text { Mean } \\
\text { depend } \\
\text { et var }\end{array}$ & 8.540415 \\
\hline $\begin{array}{l}\text { Adjusted } \\
\text { R-squared }\end{array}$ & 0.737471 & $\begin{array}{l}\text { S.D. } \\
\text { depend } \\
\text { ent var }\end{array}$ & 19.34850 \\
\hline S.E. of & & Sum & \\
\hline $\begin{array}{l}\text { Regressio } \\
\mathrm{n}\end{array}$ & 9.913703 & $\begin{array}{l}\text { squared } \\
\text { resid } \\
\text { Durbin- }\end{array}$ & 1955.630 \\
\hline F-statistic & 13.17278 & $\begin{array}{l}\text { Watson } \\
\text { stat }\end{array}$ & 2.270221 \\
\hline $\begin{array}{l}\text { Prob (F- } \\
\text { statistic) }\end{array}$ & 0.000005 & & \\
\hline
\end{tabular}

Sumber: Data diolah,2019.

Analisa Regresi Berganda

Pengujian Model Estimasi

Pengujian model terbaik dilakukan dengan menggunakan likelihood ratio untuk mengetahui apakah model common effect atau fixed effect yang dipilih, sedangkan untuk mengetahui pilihan terbaik antara fixed effect model (FEM) atau random effect model (REM) yang terpilih dilakukan uji Hausman. Hasil uji chow dapat dilihat pada tabel 8. 
Tabel 8. Hasil Uji Chow

\begin{tabular}{lccc}
\hline \multicolumn{1}{c}{ Effect Test } & Statistic & d.f. & Prob \\
\hline \hline Cross-Section F & 3.825696 & $(8.12)$ & 0.0184 \\
Cross-section Chi-square & 34.211114 & 8 & 0.0000 \\
\hline Sumber: Data diolah, 2019 & & &
\end{tabular}

Berdasar hasil uji chow diperoleh probabilitas cross-section Chi Square yang lebih kecil dari 0.05 sehingga model fixed effect (FEM) yang terpilih daripada model common effect. Setelah terpilih model FEM maka dilakukan uji Hausman untuk memilih antar model fixed effect dan random effect (REM). Hasil uji Hausman dapat dilihat pada tabel 9.

\begin{tabular}{llll}
$\begin{array}{l}\text { Equation: RANDOMMOD } \\
\text { Test cross-section random effect }\end{array}$ & & \\
\hline \hline Test Summary & $\begin{array}{l}\text { Chi-Sq. } \\
\text { Statistic }\end{array}$ & $\begin{array}{l}\text { Chi-Sq. } \\
\text { d.f. }\end{array}$ & Prob. \\
& & & \\
\hline \hline Cross-section random & 0.000000 & & 1.0000 \\
\hline \hline
\end{tabular}

Dari tabel 9, kita dapat melihat bahwa probabilitas chi Square memiliki nilai lebih besar dari 0.05 sehingga dapat disimpulkan bahwa model random effect (REM) yang terpilih.

Goodness of Fit Model

Goodness of Fit Model dilakukan untuk menilai seberapa besar model dapat digunakan untuk memprediksi tingkat perubahan variabel dependen dengan menggunakan nilai $R$-Square dan Adjusted $R$ Square. Hasil pengujian Goodness of Fit Model dapat dilihat pada tabel 10.

Tabel 10. Hasil Uji Goodness of Fit Model

\begin{tabular}{lrrr}
\hline \multicolumn{1}{c}{ Variabel } & Koefisien & t-statistik & probabilitas \\
& & & \\
\hline C & 157.7344 & 1.485207 & 0.1531 \\
LICR & -15.92117 & -3.624775 & 0.0017 \\
DTAMOD2 & 6.687990 & 0.351918 & 0.7286 \\
LIJK & 6.860268 & 1.599086 & 0.1255 \\
LINF & 6.4433165 & 5.221133 & 0.2322 \\
INT & -9.130856 & 2.862134 & 0.0461 \\
TDL & -0.159188 & -1.492494 & 0.1512 \\
\hline R-Square & & 0.798055 & \\
Adjusted R- & & 0.737471 & \\
Squared & & & \\
\hline F Statistic & & & 13.17278 \\
Prob. (F- & & & 0.000005 \\
Stat) & & & \\
\hline
\end{tabular}

Sumber: Data diolah, 2019 
Nugraheni Siwi: Determinan Profitabilitas ...

Berdasarkan tabel 10 diperoleh nilai Adjusterd R-Squared sebesar 0.737471 yang berarti sebesar $73.7471 \%$ perubahan variabel ROA atau profitabilitas dapat dijelaskan oleh variabel independen yaitu variabel likuiditas (LICR), variabel debt to total asets (DTAMOD2), variabel jumlah karyawan (LIJK), variabel inflasi (LIINF), variabel suku bunga (INT), dan variabel tarif dasar listrik (TDL), sedangkan sisanya sebesar $26.2529 \%$ dijelaskan oleh variabel lain. Hasil Adjusted $R$ squared diatas $50 \%$ menunjukkan model penelitian cukup bagus digunakan untuk memprediksi perubahan variabel dependen oleh variabel independen.

\section{Uji Parsial}

Pengujian parsial dilakukan untuk mengetahui bagaimana pengaruh masingmasing variabel independen terhadap variabel dependen. Dari tabel 10 dapat kita lihat bahwa ada dua variabel yang memiliki nilai probabilitas $t$-statistic lebih kecil dari 0.05 yaitu variabel likuiditas (LICR) yang merupakan faktor internal dan variabel suku bunga (INT) yang merupakan faktor eksternal. Sedangkan variabel lainnya memiliki nilai probabilitas $t$ statistic lebih besar dari 0.05. Jadi dapat disimpulkan bahwa secara parsial hanya variabel likuiditas dan suku bunga yang memiliki pengaruh signifikan terhadap variabel ROA (profitabilitas). Nilai koefisien variabel likuiditas dan suku bunga yang negatif menunjukkan variabel likuiditas dan suku bunga berpengaruh negatif dan signifikan terhadap ROA.

\section{Uji Simultan}

Uji simultan dilakukan untuk melihat apakah semua variabel independen secara simultan berpengaruh signifikan terhadap variabel dependen. Hasil pengujian secara simultan dapat dilihat pada tabel 10 yang menunjukkan nilai probabilitas F-statistic memiliki nilai lebih kecil dari 0.05 , sehingga dapat disimpulkan bahwa secara simultan faktor internal dan eksternal berpengaruh signifikan terhadap profitabilitas perusahaan.

\section{Pembahasan Hasil Penelitian \\ Pengaruh Faktor Internal \\ Pengaruh Likuiditas terhadap Profitabilitas}

Dari hasil regresi diperoleh nilai koefisien likuiditas -15.92117 yang berarti setiap kenaikan likuiditas sebesar $1 \%$ akan menurunkan profitabilitas perusahaan TPT sebesar $15.92117 \%$. Nilai probabilitas $t$ statistic yang diperoleh lebih kecil dari 0.05 sehingga dapat dikatakan variabel likuiditas berpengaruh negatif dan signifikan terhadap profitabilitas perusahaan TPT. Hasil penelitian ini sesuai dengan penelitian yang dilakukan Purwadi (2013) yang menunjukkan adanya pengaruh negatif dan signifikan faktor likuiditas terhadap profitabilitas perusahaan. Kelebihan likuiditas pada perusahaan TPT ternyata akan menimbulkan dana menganggur (idle fund) yang berpengaruh negatif terhadap profitabilitas. Manajer keuangan harus menentukan dengan tepat jumlah likuiditas yang cukup agar tidak terjadi kekurangan likuiditas yang bisa mengganggu proses produksi tetapi juga tidak terjadi kelebihan likuiditas dimana dana yang ada sebenarnya bisa digunakan untuk kegiatan produktif. Halhal yang bisa dilakukan untuk melakukan manajemen risiko likuiditas adalah sebagai berikut:

1. Melakukan analisa dan proyeksi terhadap cash flow sehingga perusahaan bisa mengetahui adanya kebutuhan likuiditas yang mungkin terjadi di masa depan.

2. Melakukan mitigasi krisis likuiditas, yaitu dengan mengambil tindakan ketika sudah ada indikasi negatif yang berkaitan dengan likuiditas.

3. Liqudity risk bearing analysis

Analisa ini dilakukan dengan mengevaluasi manfaat dan biaya yang berkaitan dengan pemenuhan kebutuhan likuiditas perusahaan.

4. Menetapkan limit kebutuhan likuiditas perusahaan 
Dengan menggunakan trend kebutuhan likuiditas berdasarkan riwayat kebutuhan likuiditas di masa lalu, perusahaan bisa menetapkan limit kebutuhan likuiditas agar tidak terjadi kelebihan maupun kekurangan likuiditas.

\section{Pengaruh Debt to Total Assets terhadap Profitabilitas}

Nilai koefisien debt to total assets 6.687990 menunjukkan bahwa setiap kenaikan debt to total assets sebesar $1 \%$ akan menaikkan profitabilitas sebesar 6.687990 . Meskipun dari nilai probabilitas t-statistic debt to total asset tidak berpengaruh signifikan terhadap profitabilitas, tetapi nilai koefisien yang positif menunjukkan manajemen utang yang dilakukan perusahaan TPT sudah cukup baik karena pembiayaan aset dari utang memberikan kontribusi positif terhadap profitabilitas.

\section{Pengaruh Jumlah Karyawan Terhadap Profitabilitas}

Nilai koefisien jumlah karyawan 6.860268 menunjukkan bahwa setiap kenaikan jumlah karyawan sebesar $1 \%$ akan menaikkan profitabilitas perusahaan TPT sebesar 6.860268\%. Meskipun nilai probabilitas $t$-statistic menunjukkan pengaruh tidak signifikan akan tetapi nilai koefisien yang positif menunjukkan bahwa kinerja karyawan perusahaan TPT selama ini cukup baik sehingga bisa memberikan kontribusi positif terhadap profitabilitas. Hal ini dapat terjadi karena tingkat produktivitas karyawan perusahaan TPT di Indonesia memang salah satu yang tertinggi di Asia Tenggara (Horne,2018).

\section{Pengaruh Faktor Eksternal Pengaruh Inflasi}

Nilai koefisien korelasi inflasi sebesar 6.433165 menunjukkan setiap kenaikan inflasi $1 \%$ justru akan menaikan profitabilitas perusahaan TPT sebesar $6.433165 \%$. Hasil ini berbeda dengan penelitian terdahulu yang dilakukan oleh Purwadi (2013) yang menyatakan adanya pengaruh negatif dan signifikan inflasi terhadap profitabilitas perusahaan TPT. Kontribusi positif inflasi terhadap profitabilitas dimungkinkan karena dengan inflasi akan menyebabkan penurunan nilai rupiah yang biasanya berimbas terhadap naiknya ekspor. $70 \%$ perusahaan TPT adalah perusahaan yang berorientasi ekspor, sehingga terjadinya inflasi akan memacu peningkatan ekspor tekstil dan produk tekstil yang menimbulkan peningkatan profitabilitas. Bagi perusahaan TPT yang berorientasi pasar domestik, peningkatan laju inflasi akan memeberikan dampak negatif karena inflasi akan mengurangi daya beli konsumen. Untuk mengatasi hal tersebut sebaiknya perusahaan TPT yang berorientasi pasar domestik perlu menerapkan strategi harga produk yang kompetitif sehingga bisa dijangkau oleh konsumen. Pemerintah sebaiknya membantu perusahaan TPT dengan mengurangi bea ekspor dan kebijakan proteksi terhadap industri TPT dari serbuan impor sebagai imbas penerapan Asean China Free Trade Area (ACFTA) tahun 2015.

\section{Pengaruh Suku Bunga}

Koefisien suku bunga sebesar -9.130856 menunjukkan setiap kenaikan suku bunga sebesar $1 \%$ akan menurunkan profitabilitas sebesar $9.130856 \%$. Nilai probabilitas $t$ statistic yang lebih kecil dari 0.05 menunjukkan adanya pengaruh negatif dan signifikan suku bunga terhadap profitabilitas perusahaan TPT. Hasil ini sejalan dengan penelitian yang dilakukan oleh Hermawan (2011) dan Purwadi (2013) yang menemukan adanya pengaruh negatif suku bunga terhadap profitabilitas perusahaan TPT. Kontribusi negatif suku bunga mengindikasikan perusahaan TPT harus bisa mengelola pinjaman terhadap bank dengan baik karena peningkatan jumlah pinjaman akan mengakibatkan peningkatan beban bunga 
Nugraheni Siwi: Determinan Profitabilitas ...

yang harus dibayar yang berimbas negatif terhadap profitabilitas. Perusahaan TPT sebaiknya memiliki alternatif sumber pembiayaan selain utang bank, misalnya dengan menggunakan laba ditahan (retained earning) yang memiliki risiko lebih kecil sehingga beban bunga akibat pinjaman dari bank bisa ditekan.

\section{Pengaruh Tarif Dasar Listrik}

Nilai koefisien tarif dasar listrik diketahui sebesar -0.159188, hal ini menunjukkan bahwa setiap kenaikan tarif dasar listrik untuk golongan industri akan menyebabkan penurunan profitabilitas perusahaan. Meskipun nilai probabilitas $t$ statistic menunjukkan tidak adanya hubungan yang signifikan, namun nilai koefisien yang negatif menunjukkan bahwa pemerintah perlu melakukan pengkajian yang mendalam dalam menetapkan tarif dasar listrik untuk golongan industri terutama industri TPT karena peningkatan tarif dasar listrik akan meningkatkan beban operasional perusahaan yang berimbas negatif terhadap profitabilitas perusahaan TPT. Sebaiknya dalam penetapan kebijakan TDL, pemerintah melibatkan perusahaan TPT misalnya melalui rapat dengar pendapat dengan DPR agar kebijakan TDL yang ditetapkan tidak terlalu membebani perusahaan TPT. Salah satu kebijakan Pemerintah untuk meningkatkan daya saing perusahaan TPT adalah tidak mencabut subsidi listrik untuk industri TPT sehingga beban operasional akan berkurang dan harga jual produk TPT untuk ekspor akan mampu bersaing dengan kompetitor lainnya.

\section{PENUTUP}

Berdasarkan hasil dan pembahasan dapat diambil kesimpulan sebagai berikut:

1. Secara parsial faktor internal berupa likuiditas dan faktor eksternal berupa suku bunga berpengaruh negatif dan signifikan terhadap profitabilitas perusahaan TPT. Hal ini menunjukkan pengelolaan modal kerja harus dilakukan oleh perusahaan TPT dengan baik agar tidak terjadi kekurangan ataupun kelebihan likuiditas yang bisa berpengaruh negatif terhadap profitabilitas. Perusahaan TPT harus melakukan analisa kebutuhan likuiditas berdasarkan informasi yang diperoleh dari data historis kebutuhan likuiditas sehingga tidak terjadi kelebihan maupun kekurangan likuiditas. Sebagai salah satu sumber pembiayaan, pinjaman atau utang bank memang penting akan tetapi perusahaan TPT harus bisa mengelola pinjaman bank dengan baik karena beban bunga yang harus dibayar bisa berpengaruh negatif terhadap profitabilitas perusahaan TPT. Perusahaan harus memiliki alternatif sumber pembiayaan agar tidak bergantung pada utang bank sebagai satu-satunya sumber pembiayaan, misalnya dengan alternatif menggunakan laba ditahan sebagai sumber pembiayaan.

2. Secara simultan, faktor internal dan eksternal berpengaruh signifikan terhadap profitabilitas perusahaan TPT sehingga perusahaan TPT harus bisa mengelola faktor yang berasal dari dalam perusahaan seperti rasio keuangan dengan baik agar bisa memperoleh profitabilitas yang diharapkan. Terkait dengan faktor eksternal, demi kemajuan industri TPT, pemerintah sebagai pihak yang berperan dalam menerapkan kebijakan, harus melakukan pengkajian secara mendalam dan melibatkan perusahaan TPT dalam menetapkan tarif dasar listrik terutama untuk golongan industri agar perusahaan tidak terbebani dengan tarif dasar listrik sehingga bisa menetapkan harga jual yang kompetitif agar bisa memiliki daya saing tinggi di pangsa pasar terutama pasar dunia melalui ekspor. Pemerintah juga harus mengantisipasi dampak negatif yang mungkin akan timbul dari penerapan Asean China Free Trade Area (ACFTA) yang sudah dijalankan sejak tahun 2015 yaitu masuknya komoditas tekstil dan produk tekstil dari negara-negara pesaing seperti 
China dan Vietnam dengan harga yang kompetitif. Penelitian ini memiliki keterbatasan karena hanya menggunakan sampel dari perusahaan TPT yang terdaftar di Bursa Efek Indonesia dan sehingga tidak memberikan gambaran secara utuh tentang industri TPT yang berasal dari golongan kecil dan menengah (UMKM). Diharapkan penelitian selanjutnya juga menggunakan UMKM di bidang tekstil dan produk tekstil sehingga hasilnya akan lebih memberikan gambaran yang menyeluruh mengenai pengaruh kebijakan Pemerintah terhadap industri TPT di Indonesia.

\section{REFERENSI}

\section{Jurnal dan Buku:}

Abaidoo, R., and Ofosuheno, D. (2013). Corporate Profit Growth, Macroeconomic Expectation and Fiscal Policy Volatlity. Canadian Center of Science and Education.Vol. 5. pp 29-38.

Abdi, S.P., dan Rianse, U. (2012). Metodologi Penelitian Sosial dan Ekonomi. Edisi 1. Bandung: Alfabeta.

Anand, M. (2014). A Study of Financial Analysis in Textile Sector. Journal of Business Management and Social Researches. Vol. 3 pp. 2-7.

Bekeris, R. (2012). The Impact of Macro Economic Indicators Upon SME's Profitability in Lithuania. Ekonomika, Vol. 9. pp 124-136

Brigham, Eugene, F. (1993). Fundamental of Financial Management. Fifth Edition. New York, USA: The Dryden Press.

Cekrezi, A. (2015). The Impact of Macroeconomic Condition on SME's Profitability in Albania. Global Journal for Research Analysis, Vol. 4. pp 2-3.

Eljelly, A. (2004). Liquidity-Profitability Trade Off: An Empirical Investigation in An Emerging Market. International Journal of Commerce, Vol. 14 pp. 48-61.
Gujarati dan Porter. (2009). Dasar-Dasar Ekonometrika. Edisi1. Jakarta: Salemba Empat.

Hady, H. (2005). Manajemen Keuangan Internasional. Edisi1. Jakarta: Mitra Wacana Media.

Herawati, V. (2010). Analisis Pengaruh Asean China Free Trade Area terhadap Kinerja Keuangan yang Dilihat dari Penjualan pada UKM Tekstil Di Pekalongan. Skripsi Program S1 Ekonomi. Universitas Diponegoro

Hermawan, I. (2011). Analisis Dampak Kebijakan Makro Ekonomi Terhadap Perkembangan Industri Tekstil dan Produk Tekstil Indonesia. Jurnal Bank Indonesia, Vol.13.hal 28-55.

Hidayat., Latief, D. (2016). Pengaruh Biaya Produksi Dan Penjualan Terhadap Profitabilitas Perusahaan Manufaktur Sektor Industri Dasar Dan Kimia Yang Terdaftar Di BEI Tahun 2010-2014. Jurnal Widyatama. Vol.1. hal. 42-54.

Horne, R. (2018). Pertumbuhan Ekspor dan Lapangan Kerja Sektor Garmen Indonesia. Buletin Sektor Garmen dan Alas Kaki Indonesia. Edisi I. hal 1-12.

Mansour, E and Muhammad. (2012). The Effect of Working Capital Management and Profitability: Evidance From Singapore. Interdisciplinary Journal of Contemporary Research in Business. Vol. 4. pp 427-480.

Manoj, G. (2015). Profitability Analysis oh Indian Textiles Industries in The Post of MFA Regime. Glacier Journal of Scientific Research. Vol. 3. pp 5-11.

Margaretha, F. (2014). Dasar-Dasar Manajemen Keuangan. Edisi dua. Jakarta: Dian Rakyat.

Nophirin. (1995). Ekonomi Moneter. Edisi ketiga. Yogyakarta: BPFE.

Owalobi, SA, Obiakor, RT, Okwu, AT. (2011). Investigating Liquidity- Profitability Relationship in Business. British Journal 
Nugraheni Siwi: Determinan Profitabilitas ...

of Economic, Finance, and Sciences, Vol. 1, pp 8-19.

Purwadi, T. (2013). Analisis Faktor Internal dan Eksternal terhadap Profitabilitas Perusahaan Tekstil Yang Go Publik Di Bursa Efek Indonesia Tahun 2005-2011. Tesis Magister Manajemen. Institut Pertanian Bogor.

Riyanto, B. (2008). Dasar-Dasar Pembelanjaan Perusahaan. Edisi kelima. Yogyakarta: BPFE.

Raheman and Nasr, M. (2007). Working Capital Management and Profitability. International Review of Business Research Papers, Vol 5 pp. 1-14

Salvatore, D. (2003). Prinsip-Prinsip Ekonomi. Edisi ketiga. Jakarta: Erlangga.

Sawir, A. (2009). Analisis Kinerja Keuangan dan Perencanaan Keuangan Perusahaan. Edisi kelima. Jakarta: Gramedia.

Shochrul. R, Ajija dkk. (2011). Cara Cerdas Menguasai Eviews. Edisi1. Jakarta: Salemba Empat.

Syamsudin, L. (2001). Manajemen Keuangan Perusahaan. Edisi ketiga. Jakarta: Raja Grafindo Persada.

Tasim, T., Mulyana, B. (2018). Faktor Internal, Faktor Eksternal, dan Harga Saham (Studi Kasus Perusahaan Tekstil dan
Garmen Yang Terdaftar di BEI Tahun 2012-2017). Jurnal EMBA, Vol. 4. hal 91108.

Widarjono, A. (2007). Ekonometrika: Teori dan Aplikasi Untuk Ekonomi dan Bisnis. Edisi 1. Yogyakarta: Ekonesia FE UII.

Wiharja, Y., Natalia, C. (2013). Dampak Kenaikan Tarif Dasar Listrik terhadap Industri Rumah Tangga di Indonesia dengan Model Computabel General Equilibirium. Jurnal Metris Unika Atma Jaya. Vol. 14. hal 141-387.

Winarno, W. (2011). Analisis Ekonometrika dan Statistika Dengan Eviews. Edisi kedua. Yogyakarta: UPP STIM YKPN.

\section{Website:}

bps.go.id. (2019, 25 Februari). Ekspor Pakaian Jadi Dari Tekstil Menurut Negara Tujuan Utama 2012-2017. Diakses 16 Mei 2019 dari: https://bps.go.id/staticable/2019//0 2/25/2026/ekspor-pakaian-jadikonveksi-dari-tekstil-menurutnegara-tujuan-utama-2012-2017

Investor.id (2019, 20 Juni). Industri TPT Kita., Tersedia di: https://investor.id/editorial/industritpt-kita [diakses 6 September 2019] 